\title{
Assessing the Islamic Banks Performance in the Gulf Cooperation Council Countries: An Empirical Study
}

\author{
Assaf Filfilan ${ }^{1}$ \\ ${ }^{1}$ Department of Accounting, College of Business, University of Jeddah, Jeddah City, Kingdom of Saudi Arabia \\ Correspondence: Assaf Filfilan, Department of Accounting, College of Business, University of Jeddah, Jeddah City, \\ Kingdom of Saudi Arabia.
}

Received: July 5, 2020

Accepted: August 27, 2020

Online Published: September 13, 2020

doi:10.5430/rwe.v11n5p361

URL: https://doi.org/10.5430/rwe.v11n5p361

\begin{abstract}
This paper aims to ask lots of questions about the effect of various factors on the performance of the Islamic Banking Sector (IBS) in the Gulf Cooperation Council (GCC) countries. Both panel data analysis relating to random effect (RE) regression and generalized method of moments (GMM) in the system are utilized to quantify the relationship between board features and banks performance. The population of this research was 40 Islamic banks in the GCC zone with the perception went from 2005 to 2016. Our outcomes point to show that regression with GMM in system confirms the RE results just for the degree of bank capital, demonstrating a positive and significant connection between this variable and the bank performance at a 5\% criticalness level. Notwithstanding, sharia board size and board duality apply a positive and huge hit on bank performance just when RE regression technique is utilized. These discoveries are applicable and valuable contribution for Islamic banks in dealing with their speculations inside their establishments. All the more significantly, Islamic banks in GCC should allow more significance to the degree of the capital bank, the structure and nature of the board, and the board duality to improve their performance.
\end{abstract}

Keywords: Islamic banks, bank performance, panel data, GCC

\section{Introduction}

A few empirical studies have tried to decide out the effect of internal authority and control mechanisms on banking performance in an Islamic big picture. Regardless of whether some fruitful endeavours have been now made in this field, the outcomes are opposing. In a review of the literature dealing with Islamic financial execution and its relationship with inside control factors, a few examinations have discovered a non-linearity in the relationship, while different investigations have demonstrated more grounded resembling a line.

Matoussi and Grassa (2012) dealt with an examination of 90 Islamic banks from two GCC countries of Southeast Asia during the period 2000-2009. They found that duality positively affected performing Islamic banks. The nearness of the boss with bookkeeping and additionally monetary aptitudes in the SSB emphatically influences the bank's performance. Al-Tamimi and Jelali (2013) did an examination on 15 public banks in the United Arab Emirates by over the period 1998-2010. The outcomes show that institutional chiefs on the directorate are emphatically associated with performance.

Wasiuzzaman and Gunasegavan (2013) use in a comparative report an example of 14 Malaysian banks, nine of which are conventional and five Islamic banks contemplated during the period 2005-2009. They find that the size of the board positively affects performing Islamic banks. Additionally, an independent non-leader chief has no impact on bank execution. Rachdi (2014) did an investigation of 29 Malaysian Islamic banks over the period 2000 to 2011. He demonstrated that the mix of senior supervisor president capacities and an individual from the Sharia bunch with abilities in money or potentially in bookkeeping does not influence performance.

Based on a sample composed of 53 Islamic banks and covering 15 countries during the examination time frame 2005 to 2009, Zouari and Taktak (2012) show that institutional supervisors on the top managerial staff are contrarily associated with performance. In nearly a similar report, Bukhari, and Abdul Rahman (2015) utilized 40 Islamic banks working in GCC nations from 2008 to 2011. The authors show that the size of the board exacerbates performance. Additionally, the size of the board improves Return of Equity (ROE) and an awful impact on Return of Assets (ROA). The blend of the elements of the overseeing chief and president does not influence bank performance. 
Daly and Frikha (2017) utilized 67 Islamic banks (42 Islamic banks from GCC nations and 25 Islamic banks (SAC)) during the period 2004-2012. They show that the duality of the overseeing chief and president decidedly influences bank performance. The nearness of a Sharia board part with money as well as bookkeeping abilities decidedly influences performance. Mullah and Zaman (2015) utilize 86 Islamic banks covering 25 countries for a long time from 2005 to 2011. The size of the bank's directorate is adversely identified with bank performance. The mix of the elements of the overseeing chief and president contrarily influences bank performance. The nearness of autonomous chiefs on the top managerial staff is contrarily associated with performing organizations. The size of the Sharia board emphatically influences performance.

In the not so distant past, Mkadmi and Hamlaoui (2016) utilized 17 Malaysian Islamic banks saw more than 7 years from 2005 to 2011. The size of the board of directors improve Return on Assets (ROA) and Return on Equity (ROE). The nearness of a free non-chief expands ROA and ROE. Idris et al., (2011) utilized 11 Australian banks during the period somewhere in the range of 1999 and 2013. The size of the board positively affects ROA. Bodibe et al., (2016) utilize 15 Malaysian banks for the period from 2008 to 2015. The size of the sharia board decidedly influences bank performance: the size of the sharia board emphatically influences ROA and ROE. The nearness of a Sharia board part with money and additionally bookkeeping abilities emphatically influences performance. AlQanea and Hamden (2017) utilize 30 Islamic banks in GCC nations for the period (2012-2014). They show that there is a negative impact on the autonomy of the board on performing Islamic banks. Sobhy et al., (2017) utilize 159 banks during the 2009-2013 period in ten Asian nations. The authors find that size of the bank and independence of the board has a positive relationship with the bank executives. Notwithstanding, duality has a negative relationship with performance.

The vast majority of the past examinations are recognized by the way that Islamic banks are essentially missing from investigations. For us, it is unique in relation to what has been accounted for in the writing. This paper focuses to coordinate the Islamic financial part in the examination to see genuine components which can influence their performance.

The remainder of this paper is structured as follow. Section 2 details the methodology of the analysis, in particular, used variables and model formulation. Section 3 describes the statistical analysis including results and diagnostic checks. Some remarks and conclusion are presented in section 4.

\section{Materials and Methods}

\subsection{Study Area and Data}

Our set of data relates to six (6) countries, to be specific the Arabia Saudi, United Arab Emirates, Bahrain, Oman, Kuwait, and Qatar. The emphasis is on the GCC locale since it turns into a pioneer in the realm of Islamic fund. The number of Islamic banks in every country, and the yearly information identifying with the financial statements of each bank, were gathered by straightforwardly counselling the Islamic Banks and Financial Institutions Information (www.ibisonline.net). Information on the structure of Board of Directors (BD) and the Sharia Board (SB) were gathered physically from the yearly reports and by counselling the site of the banks which are the subject of our examination. Therefore, our example contains 40 Islamic banks and covers six countries whose information gathered traverses a 12-years' time span from 2005 to 2016 under Table 1.

Table 1. Distribution of Islamic banks by country

\begin{tabular}{lc}
\hline Country & Number of Islamic banks per country \\
\hline Saudi Arabia & 7 \\
Bahrain & 19 \\
Emirates Arabes Unis & 4 \\
Kuwait & 4 \\
Oman & 2 \\
Qatar & 4 \\
\hline Total & 40 \\
\hline
\end{tabular}




\subsection{Variables}

Following Bodibe et al., and (2016), Abdul Rahman (2015), we utilize the Return of Assets (ROA) to gauge the performance of Islamic banks in GCC countries. Based on the literature review (Wasiuzzaman and Gunasegavan, 2013; Matoussi and Grassa, 2012; El-Chaarani, 2014; Daly and Frikha, 2015; Nessibi, 2016; Isik and Ince, 2016), we can remove six rules of the governing body and sharia liable to improve the performance of Islamic banks in GCC countries. This basically includes the Board size (BSIZE), the blend of the situation of overseeing chief and the director of the governing body (DUAL), autonomous non-leader chiefs (BOUT), institutional executives (BINS), the size of the Sharia board (SBSIZE) lastly the ability in fund and bookkeeping (SBINS). Nonetheless, different components can likewise impact the presentation of Islamic banks in GCC countries. We are fairly restricted to the most applicable pointers, for example, the size of the Bank (SIZE) and the degree of Bank capital (LEV). Synopsis measurements of the factors referenced above are introduced in Table 2.

Table 2. Summary statistics of variables used in Model 1

\begin{tabular}{lccccc}
\hline Variable & Mean & St. Dev & Min. & Max. & Observation \\
\hline ROA & 0.0235 & 0.1221 & -0.3915 & 0.8123 & 480 \\
BSIZE & 6.4631 & 1.9498 & 3.000 & 19.000 & 480 \\
DUAL & 0.5012 & 0.2533 & 0.000 & 0.9878 & 480 \\
BOUT & 0.2694 & 0.4389 & 0.000 & 3.000 & 480 \\
BINS & 0.6998 & 0.4986 & 0.000 & 3.000 & 480 \\
SBSIZE & 4.7716 & 0.9991 & 2.000 & 10.000 & 480 \\
SBINS & 0.40112 & 0.1334 & 0.2697 & 0.7825 & 480 \\
SIZE & 15.4362 & 2.1154 & 11.1743 & 13.7598 & 480 \\
LEV & 0.8939 & 0.5987 & 0.1126 & 1.1433 & 480 \\
\hline
\end{tabular}

Source: author's calculation

Table 2 sums up the means, the standard deviation (St. Dev), the minimums (Min), and the maximums (Max) of the variables that have an impact on the performance of the Islamic Banks. This table shows variable estimating performance has an average value of 0.0235 . Likewise, descriptive statistics uncover that the greatest estimation of ROA is 0.8123 nonetheless, the base worth is -0.3915 .

\subsection{Model Formulation}

We utilize 480 perceptions gave from two-dimensional Panel information with the end goal that 40 individual Banks and 12 years of transient information. The information estimating Islamic banks performance in GCC nations is ROA. To control singular heterogeneity, decrease the issues related with multicollinearity and estimation, we utilize the panel data model (Robert et al., 2015).

$$
\begin{gathered}
\mathrm{ROA}_{i t}=\alpha+\beta_{1} \mathrm{BSIZE}_{i t}+\beta_{2} \mathrm{DUAL}_{i t}+\beta_{3} \mathrm{BOUT}_{i t}+\beta_{4} \mathrm{BINS}_{i t}+\beta_{5} \mathrm{SBSIZE}_{\mathrm{it}}+\beta_{6} \\
\mathrm{SBINS}_{i t}+\beta_{7} \mathrm{SIZE}_{i t}+\beta_{8} \mathrm{LEV}_{i t}+\varepsilon_{\mathrm{it}}
\end{gathered}
$$

Where,

- $i=1, \ldots, 40$, an individual dimension (cross section)

- $t$ is a temporal dimension $(t=2005,2006, \ldots, 2016)$.

- $\alpha$ is a constant

- $\beta_{1}, \ldots, \beta_{8}$ measuring the impact the retained variables on the performance of the banks.

- $\varepsilon_{i t}$ measures the model error

Two strategies for assessing the boundaries of models 1 have been proposed in the literature (Domont; 1989); Ordinary Least Squares and Generalized Least Squares. The detailed test proposed by Hausman (1978) makes it conceivable to pick between these two strategies by contrasting the presentation of two estimators (Muhammad et al., 2015). Authors like Arellano and Bover (1995), Blundell and Bond (1998) propose the Sragen/Hansen over-distinguishing proof test, to check the legitimacy of the instruments. Additionally, they offer the second-request 
autocorrelation test to test the speculation of non-relationship of the error term. Note that the error term in the first distinction is associated with that of the primary request yet ought not to be had the second request.

\subsection{Correlation Matrix}

Multicollinearity might be an issue that we have to focus on, given that a similar variable may show up in the investigation more than once. To distinguish potential multicollinearity issues, tests were raced to gauge the degree of multicollinearity among the autonomous factors. The outcomes are introduced in Table 3.

Table 3. Correlation matrix for model 1

\begin{tabular}{|c|c|c|c|c|c|c|c|c|c|}
\hline & ROA & BSIZE & DUAL & BOUT & BINS & SBSIZE & SBINS & SIZE & LEV \\
\hline ROA & 1 & & & & & & & & \\
\hline BSIZE & 0.0325 & 1 & & & & & & & \\
\hline DUAL & 0.1133 & -0.0481 & 1 & & & & & & \\
\hline BOUT & 0.0175 & 0.1375 & -0.1380 & 1 & & & & & \\
\hline BINS & 0.1419 & 0.0743 & -0.0355 & -0.1113 & 1 & & & & \\
\hline SBSIZE & 0.0282 & -0.1514 & 0.1425 & -0.0715 & 0.1717 & 1 & & & \\
\hline SBINS & 0.1163 & -0.1369 & 0.1654 & -0.1372 & 0.1212 & -0.0355 & 1 & & \\
\hline SIZE & 0.0152 & 0.0249 & -0.0214 & 0.1111 & 0.0067 & 0.1669 & -0.0322 & 1 & \\
\hline LEV & 0.0423 & -0.1220 & 0.3256 & -0.1777 & 0.1188 & 0.0216 & -0.0778 & 0.2224 & 1 \\
\hline
\end{tabular}

Source: author's calculation

Table 3 shows the correlation matrix that indicates relatively low correlation coefficients between retained variables, in the range of $r=-0.1514$ to $r=0.3256$. Consequently, the multicollinearity among the independent variables could be ruled out given the results and the levels of statistical correlations (cf. Table 3).

\section{Statistical Analysis}

\subsection{Results}

The initial segment of our outcomes concerns model 1 utilizing the summed up least-square irregular impact (GLS RE). The outcomes got from this model show that the capitalization of the bank (LEV) will in general influence the productivity of advantages emphatically and fundamentally (coef. $=0.175, \mid t-$ student $\mid=2.083$ ), and thus create a working benefit with a huge coefficient at $5 \%$. This outcome underpins that Islamic keeps money with adequate capital are more productive (Sinkey and Greenawalt, (1991)). This finding, in any case, was not found by Fallatah and Dikins (2012). The second factor that affects the gainfulness of assets is the duality of bearing (DUAL). Table 4 shows that duality of bearing essentially and emphatically influences the gainfulness of benefits (coef. $=0.345, \mid t-$ student $\mid=3.113$ ) at 5\%. This outcome joins towards the aftereffect of Matoussi and Grassa (2012) however not in accordance with that found by Fallatah and Dikins (2012). At last, the shariah board (SBZISE) appears to have had a positive and noteworthy impact (coef. $=0.297, \mid t-$ student $\mid=1.993$ ) on the performance of Islamic banks in the GCC countries. In addition, this outcome generally repudiates that of Garassa and Matoussi (2012) which found that the size of the shariah board isn't noteworthy and it unfavourably influences the arrival on capital for Islamic banks in the GCC countries and South East Asia (Table 4).

Table 4. Summary statistics of variables for both GLS RE and GMM in system methods

\begin{tabular}{lcccc}
\hline \multirow{2}{*}{ Variables } & \multicolumn{2}{c}{ GLS RE } & \multicolumn{2}{c}{ GMM in system } \\
\cline { 2 - 5 } & Coeff. & $\mid t-$ Student $\mid$ & Coeff. & $\mid t-$ Student $\mid$ \\
\hline Constant & -2.379 & 0.373 & 0.738 & 0.681 \\
\hline SIZE & 0.221 & 0.958 & -0.044 & 1.022 \\
\hline LEV & $0.175^{*}$ & 2.083 & $1.102^{*}$ & 1.985 \\
\hline
\end{tabular}




\begin{tabular}{lcccc}
\hline BINS & -0.009 & 0.281 & -0.015 & 0.224 \\
\hline DUAL & $0.345^{*}$ & 3.113 & 0.076 & 1.339 \\
\hline BOUT & -0.017 & 0.176 & 0.047 & 0.318 \\
\hline BSIZE & 0.321 & 0.777 & 0.008 & 0.505 \\
\hline SBINS & 0.079 & 0.808 & -0.887 & 0.377 \\
\hline SBSIZE & $0.297^{*}$ & 1.992 & 0.046 & 0.596 \\
\hline Observation & 480 & 480 & 480 & 480 \\
\hline
\end{tabular}

* Indicates parameters that are significant at 5\% level.

To refine the outcomes that we got in the main estimation technique, we will utilize another strategy. In this way, we are going to re-gauge the relapse by the GMM strategy which permitted us to distinguish the outcomes provided details regarding the right-hand side of Table 4. Along these lines, the second piece of our outcomes concerns a similar (model 1) however utilizing the Generalized Method of Moments in system estimator (GMM in the system). As indicated by Wintoki et al., (2012), the GMM in the system estimator has been utilized to investigate discoveries of GLS RE. We will utilize one slack of the instrumental variable to restrict the possible issue with more powerless instruments. Contrasting and the GLS RE estimator, it appears to be that solitary the LEV variable has decidedly and altogether corresponded with the performance of Islamic banks in GCC countries at 5\% level. This shows that the performance of Islamic Banks in the GCC locale increments with expanding estimations of LEV (coef. $=0.102$, |tstudent $\mid=1.985)$. This outcome infers that Islamic banks capital in GCC countries is slanted to store funding to execution better, instead of conveying it. The finding affirms that advanced by Zouari and Taktak (2012), Fallatah and Dickins (2012), and Pratomo and Ismail (2007).

\subsection{Diagnostic Checks}

On the econometric level, and under the consequences of model 1 showing up in table 5, we infer that the hypothesis of the legitimacy of the instruments isn't dismissed (the probabilities of the Sagan measurement is more prominent than 5\%, which demonstrates that the instruments are all in all exogenous). Additionally, there is no sequential autocorrelation of request 2 (the probabilities of Arrellano and Bond trial of AR (2) are more noteworthy than 5\%). This permits us to see that the GMM system model is reliable and has a decent detail of the instruments, without issues of heteroskedasticity or autocorrelations.

Table 5. Comparing GLS RE and GMM in system results using various tests

\begin{tabular}{lclc}
\hline \multicolumn{1}{c}{ GLS RE } & & \multicolumn{2}{c}{ GMM in system } \\
\hline Variables & ROA & Variables & ROA \\
\hline Observation & 480 & Observation & 480 \\
\hline Wald $\chi^{2}$ test & 13.4900 & Wald $\chi^{2}$ test & 536.4900 \\
\hline$P$-value of Wald $\chi^{2}$ & 0.0959 & $P$-value of Wald $\chi^{2}$ & 0.0000 \\
\hline $\mathrm{R}^{2}$ within & 0.1029 & Sargan test & 6.0855 \\
\hline $\mathrm{R}^{2}$ Betwin & 0.6333 & $P$-value of Sargan test & 0.9977 \\
\hline $\mathrm{R}^{2}$ Overal & 0.1413 & AR (1) test - Arrellano \& Bond & -1.003 \\
\hline Rho & 0.0000 & $P$-value AR $(1)$ & 0.3159 \\
\hline Hausman test & 4.5200 & AR (2) test-Arrellano \& Bond & -0.8304 \\
\hline$P$-value Hausman test & 0.8077 & $P$-value AR $(2)$ & 0.4063 \\
\hline
\end{tabular}

This outcome is completely in accordance with the finishes of Kablan and Yousfi (2011) directed on an example of 384 Islamic banks having a place with 17 countries between 2001-2008. Our finding is still in accordance with the outcomes found by Pratomo and Ismail (2007). Nonetheless, crafted by Rachida and al., (2011), Zouari and Taktak (2012) and that of Matoussi and Grassa (2012) are not in accordance with our outcomes and they hold a positive connection between the performance of Islamic banks and their cut. 
To be sure, a valuation for the bank's complete resources is related to an expansion in the arrival on contributed capital (ROA). The more the bank's capital builds, the higher the performance estimated by the ROA. Our finding upheld the finishes of Zouari and Taktak (2012), Fallatah and Dickins (2012) and that of Pratomo and Ismail (2007) which found a positive connection between the degree of obligation and execution, mirroring that the higher the capital the more the bank is more effective.

By concentrating on this outcome, our outcome does not meet the expectations of office hypothesis which expresses that a huge board size courtesies mastery by the chiefs and makes potential irreconcilable circumstances among chiefs and supervisors. Consequently, a divided gathering, inadequate or even hard to arrive at an agreement on choices, is set up. It doesn't substantiate crafted by Matoussi and Grassa (2012), and Masheykhi and Bazaz (2008). Notwithstanding, it is in accordance with crafted by Fallatah and Dickins (2012) completing an investigation on 94 Saudi organizations during the period from 2006 to 2009, which uncover that Saudi organizations with generally enormous sheets of chiefs can be the most effective. The speculation that we recently gave is accordingly checked. The more that the Islamic bank has broad counsel, the more they can perform better.

This relationship is as of now demonstrated by Matoussi and Grassa (2012). They contrasted 90 Islamic keeps money with 85 ordinary banks in GCC countries and Southeast Asia. They guarantee that Islamic banks are performing better than ordinary banks and that duality decidedly influences the presentation of Islamic banks. Nonetheless, it doesn't uphold the examination by Al-Manaseer and al., (2012) who directed an investigation on 15 Jordanian banks. They, subsequently, suggest that the aggregation of the two capacities is at the root that the irreconcilable circumstances of the head/specialist can be exacerbated as a result of the combination of the cycle of control and the board which contrarily influences the performance of banks. Accordingly, the investigation by Fallatah and Dickins (2012) led in a Saudi setting verifies this reflection. Our hypothesis is not checked.

This outcome is now featured by Matoussi and Grassa (2012), examined this relationship on an example of 90 Islamic banks from GCC nations and Southeast Asia, and states that the nearness of autonomous chiefs is adversely corresponded with the presentation of GCC's Islamic banks. Notwithstanding, our outcomes repudiate the office's hypothesis that the nearness of autonomous chiefs on the board is a key rule for better corporate execution (Fama and Jensen 1983). These overseers are without a doubt more qualified to direct and control supervisors. They ought to likewise limitingly affect the pioneer just as CEO conduct. Thus, the freedom of the board can guarantee better execution.

This relationship negates our assessments made in advance. This outcome is conflicting with the aftereffects of the investigation directed by Matoussi and Grassa, (2012), in view of an example of 90 Islamic banks from two nations of the Southeast Cooperation Council and the more extensive Asian nations during the period somewhere in the range of 2000 and 2009 demonstrate that the nearness of researchers with bookkeeping/fund abilities in the SSB emphatically and essentially influences the bank's exhibition. Thusly, incorporating somebody with money or potentially bookkeeping abilities in SSB is so significant and encourages the Islamic bank to increase its performance.

\section{Conclusion and Discussion}

We attempted to recognize the effect of board attributes on the performance of Islamic banks in the GCC countries. To accomplish this target, we led a contextual investigation on 40 Islamic banks during the period 2005-2016. At this stage, we received two progressed econometric methodologies. In reality, through the econometrics of static board information, factors identifying with the board banking qualities are investigated. To improve our outcomes and check the centrality of these factors, we continued to think about a second assessment technique (GMM in the system). Albeit numerous past examinations managing a similar issue, the connection between the board banking qualities and the performance of Islamic banks stays vague. Part of our outcome's contrasts from past investigations, which may vary contingent upon the examined factors and set embraced.

To close, the outcomes we arrived at appearing in table 4 permitted us to presume that the connection between the various factors identifying with the interior instruments of administration and the performance of Islamic banks in GCC relies upon the observational methodology utilized in the investigation. Measurable investigations demonstrate that relapse with GMM in the system affirms the RE results only for the degree of bank capital (LEV), showing a positive and huge relationship between this variable and the bank performance at a 5\% essentialness level. Notwithstanding, sharia board size (SBSIZE) and board duality (DUAL) apply a positive and noteworthy effect on bank performance just when RE relapse technique is utilized. For RE relapse and GMM in the framework, institutional managers (BINS) applies a negative however not altogether sway on Islamic bank performance in the GCC region. In inverse, the board size (BSIZE) is decidedly related to Islamic bank performance, however, the 
impact is not huge. Both bank (SIZE) and aptitude in money and bookkeeping (SBINS) positively affect Islamic bank performance for the RE relapse yet this impact becomes negative when GMM in the system technique is utilized. All the more critically, these factors are not fundamentally influenced Islamic bank performance in the GCC district. Also, the impact of autonomous non-chief chiefs (BOUT) changes with the pre-owned strategy in the examination. It is contrarily related with Islamic bank performance on account of RE relapse, however this relationship becomes positive when GMM in the system is utilized. The connection between these factors is not critical in the two cases. At long last, Islamic banks in GCC should concede more significance to the degree of the capital bank, the structure and nature of the board, and the board duality to improve their performance.

\section{References}

Al Manaseer, M. F., Riyad, M. A. D., \& Al-Dahiyat, M. A. I. S. (2012). The Impact of Corporate Governance on the Performance of Jordanian Banks. European Journal of Scientific Research, 67, 349-359.

AlQanea, M. K., \& Hamdan, M. M. A. (2017). Islamic banks board independence and its relation to performance in GCC countries. International Journal of Islamic Marketing and Branding, 2, 100-121.

Al-Tamimi, H. A. S., \& Jellali, N. (2013). The Effects of Ownership Structure and Competition on Risk-Taking Behavior: Evidence from UAE Conventional and Islamic Banks. The International Journal of Business and Finance Research, 7, 115-124.

Arellano, M., \& Bover, O. (1995). Another look at the instrumental variable's estimation of error components models. Journal of Econometrics, 68, 29-51.

Blundell, R., \& Bond, S. (1998). Initial conditions and moment restrictions in dynamic panel data models. Journal of Econometrics, 87, 115-143.

Bodibe. S., Chiliya, N., \& Chikandiwa, C. T. (2016). The factors affecting customers' decisions to adopt Islamic banking. Banks and Bank Systems, 11, 144-151.

Daly, S., \& Frikha, M. (2017). Determinants of bank Performance: Comparative Study Between Conventional and Islamic Banking in Bahrain. Journal of the Knowledge Economy, 8, 471-488.

El-Chaarani, H. (2014). The impact of corporate governance on the performance of Lebanese banks. International Journal of Business \& Finance Research, 8, 35-46.

Fallatah, Y., \& Dickins, D. (2012). Corporate governance and firm performance and value in Saudi Arabia. Journal of Law and Economics, 6, 10025-10034.

Hausman, J. (1978). Specification tests in econometrics. Econometrica, 46, 1251-1271.

Idris, A. R., Asari, A. H., Taufik, N. A. A., Salim, N. J., Mustaffa, R., \& Jusoff, K. (2011). Determinant of Islamic Banking Institutions' Profitability in Malaysia. World Applied Sciences Journal, 12, 1-7.

Isik, O., \& Ince, A. R. (2016). Board Size, Board Composition and Performance: An Investigation on Turkish Banks. International Business Research, 9, 74-84.

Kablan, S., \& Yousfi, O. (2011). Efficiency of Islamic and conventional banks in countries with islamic banking. MPRA Paper, 1-29.

Mashayekhi, B., \& Bazaz, M. S. (2008). Corporate governance and firm performance in Iran. Journal of Contemporary Accounting and Economics, 4, 156-172.

Matoussi, H., \& Grassa, R. (2012). Is Corporate Governance Different for Islamic Banks? A comparative analysis between the Gulf Cooperation Council context and Southeast Asia context. ERF 18th annual conference Egypt, $1-136$.

Mkadmi, J., \& Halioui, K (2013). Analyse de l'impact du conseil d'administration sur la performance des banques conventionnelles Malaisiennes. La Revue Gestion et Organisation, 5, 16-26.

Mollah, S., \& Zaman, M. (2015). Shari'ah supervision, corporate governance, and performance: Conventional vs. Islamic banks. Journal of Banking \& Finance, 58, 418-435.

Muhammad, N., Islam, A. R. M., \& Marashdeh, H. A. (2015). Financial development, and economic growth: an empirical evidence from the GCC countries using static and dynamic panel data. Journal of Economics and Finance, 40, 773-791. 
Nessibi, O. (2016). The Determinants of Bank Profitability: The Case of Tunisia. International Journal of Finance \& Banking Studies, 5, 39-50.

Pratomo, W. A., \& Ismail, A. G. (2007). Islamic Bank Performance and Capital Structure. University Library of Munich, Germany.

Rachdi, H. (2014). The Role of Banking Governance in Financial and Ethical Profitability: The Case of Malaysian Islamic Banks. Journal of Islamic, Economics, Banking and Finance, 10(3), 14-28.

Sinkey, J. F., \& Greenawlat, M. B. (1991). Loan-Loss Experience and Risk-taking Behaviour at Large Commercial Banks. Journal of Financial Services Research, 5, 43-59.

Tang, G., \& Li, D. (2015). Is there a relation between religiosity and customer loyalty in the Chinese context?. International Journal of Consumer Studies, 39, 639-647.

Wasiuzzaman, S., \& Gunasegavan, U. N. (2013). Comparative study of the performance of Islamic and conventional banks: The case of Malaysia. Humanomics, 29, 43-60.

Wintoki, M. B., James, S. L., \& Jeffry, M. N. (2012). Endogeneity, and the dynamics of internal corporate governance. Journal of Financial Economics, 105, 581-606.

Zouari, S. S., \& Taktak, N. B. (2012). Ownership structure and financial performance in Islamic banks: Does ownership matter?. The Economic Research Forum Working Paper $n^{\circ} 713$.

\section{Copyrights}

Copyright for this article is retained by the author(s), with first publication rights granted to the journal.

This is an open-access article distributed under the terms and conditions of the Creative Commons Attribution license (http://creativecommons.org/licenses/by/4.0/). 